
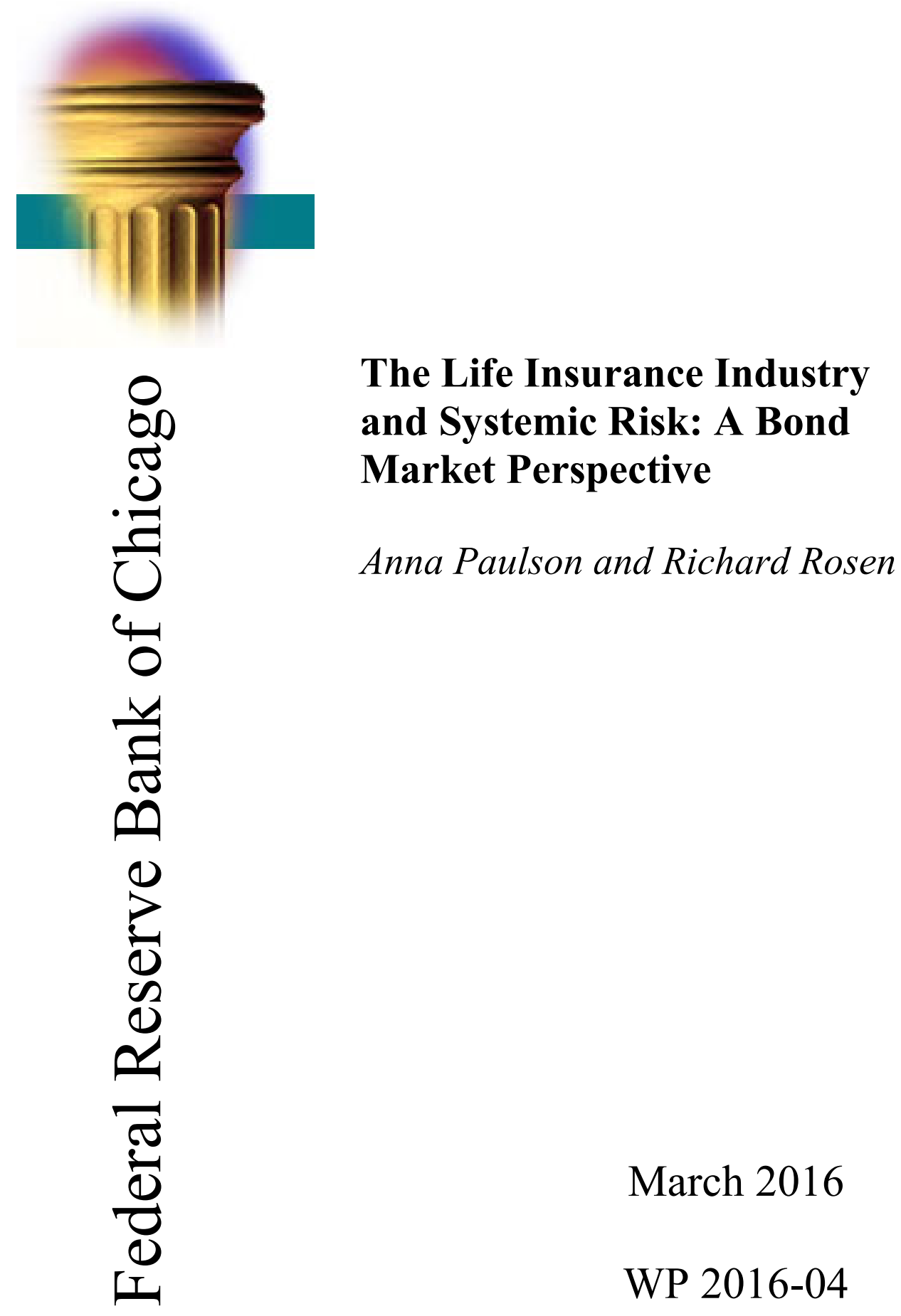


\title{
The Life Insurance Industry and Systemic Risk: A Bond Market Perspective ${ }^{1}$
}

\author{
Anna Paulson \\ Richard Rosen \\ Federal Reserve Bank of Chicago
}

March 22, 2016

\begin{abstract}
The 2008 financial crisis brought a focus on the potential for a large insurance firm to contribute to systemic risk. Among the concerns raised was that a negative shock to insurers could lead to a 'fire sale' of corporate bonds, a market where insurers are among the largest participants. This paper discusses the existing evidence on life insurance firms and systemic risk, with a focus on the investment grade corporate bond market. We provide some tentative evidence that life insurers tend to absorb liquidity risk by purchasing bonds when the bonds are less liquid than average. However, we do not find evidence that insurers increased bond purchases specifically during the financial crisis leaving open the question of whether insurers would play a stabilizing role in a future crisis.
\end{abstract}

\footnotetext{
${ }^{1}$ The views presented here are those of the authors and not necessarily those of the Federal Reserve Bank of Chicago or the Federal Reserve Board. We are grateful to Andy Polacek for excellent research assistance as well as insightful comments and to Alejandro Drexler and Dan Hartley for their insights and contributions.
} 


\section{Introduction}

The 2008 financial crisis, and in particular AIG's near failure and subsequent rescue, brought a focus on the potential for a large insurance firm to contribute to systemic risk. However, the possibility that the insurance sector could be a source of systemic risk is not new. Odell and Weidenmier (2004) argue that the panic of 1907 had its roots in gold flows from British insurers who provided fire insurance in San Francisco and who made large payouts following the 1906 earthquake. Rose (2016) analyzes the 1933 resolution of National Surety and provides evidence that concerns about systemic consequences of a disorderly resolution motivated government intervention to rescue the firm. Still, the contribution of AIG to the recent financial crisis led post-crisis reformers to create mechanisms for designating insurance firms as systemically risky. Using these new tools, the G20's Financial Stability Board has determined that nine insurers are global systemically important insurance firms. Among these are three U.S. firms - AIG, Metlife and Prudential - that were also designated as systemically important by the U.S. Financial Stability Oversight Council (FSOC). Among the concerns that the FSOC raised in documents outlining the rationale for designating the U.S. insurers was the possibility that a negative shock to one of these firms could lead it to sell assets at so-called 'fire sale' prices and thereby spread the shock to other parts of the financial system. ${ }^{2}$

If a large U.S. life insurance firm were to find itself in a situation where it needed to sell substantial assets at fire sale prices, it is likely that corporate bonds would be high on the list of assets that it would sell. Of the life insurance industry's \$6.3 trillion portfolio of assets, \$2.6 trillion are corporate bonds. This accounts for $20 \%$ of all corporate bonds outstanding in the U.S., making life insurers the largest holder of U.S. corporate bonds.

Given the outsize role of life insurers in the corporate bond market, an important dimension of assessing the industry's potential contribution to systemic risk is through their interactions with the corporate bond market. The importance of understanding whether insurers play a stabilizing or destabilizing role in corporate bond markets is underscored by post-crisis changes in corporate bond markets. Dealer banks appear to have sharply reduced the resources they

\footnotetext{
${ }^{2}$ See

http://www.treasury.gov/initiatives/fsoc/designations/Documents/Basis\%20of\%20Final\%20Determination\%20Reg arding\%20American\%20International\%20Group,\%20Inc.pdf (AIG), http://www.treasury.gov/initiatives/fsoc/designations/Documents/MetLife\%20Public\%20Basis.pdf (MetLife), and http://www.treasury.gov/initiatives/fsoc/designations/Documents/Prudential\%20Financial\%20Inc.pdf (Prudential).
} 
are willing to provide make markets in corporate bonds and the share of bonds they hold in inventory has declined markedly compared to before the financial crisis (Figure 1). Reduced market making by dealers could mean that the actions of insurance firms are of additional importance in determining the health of corporate bond markets.

Given this backdrop, we review two literatures which speak to the potential systemic role of the insurance industry. The first literature largely begins after the financial crisis and seeks to directly answer the question: is the life insurance industry systemically important? The second literature examines the role of insurers in corporate bond markets. It is less directly focused on the issue of systemic risk and much of it pre-dates the crisis. This literature tackles many different issues and in doing so reveals something about interactions between the insurance sector and corporate bond markets. Our discussion of this literature is focused on what these papers imply for a possible systemic role for the insurance industry via the corporate bond market. In particular, we consider the evidence for when and how the life insurance industry contributes to stability in corporate bond markets and when it does not.

In order to more clearly articulate priorities for future research, we also present some new suggestive evidence on the role that the U.S. life insurance industry plays in corporate bond markets. In particular, we analyze the extent to which life insurance purchases of investment grade corporate bonds tend to stabilize or destabilize the market. We examine whether life insurers' purchases of a bond are related to the bond's liquidity and how this relationship has changed through time. We focus on investment grade - rather than high yield - corporate bonds because they are a much larger market and, thus, fire sales of investment grade bonds are more likely to lead to systemic problems. We find that life insurers absorb liquidity risk by purchasing bonds when the bonds are less liquid than average. However, our analysis provides no evidence that insurers increased bond purchases specifically during the financial crisis leaving open the question of whether insurers would play a stabilizing role in a future crisis.

The rest of the paper is organized as follows. The next section reviews the literature that tackles the question of whether the insurance industry contributes to systemic risk. Section 3 provides a selective overview of the literature that examines interactions between insurers and the corporate bond market. In section 4 we summarize what we have found from our analysis of insurance activities in corporate bond markets over the period from 2005 to 2014 . Section 5 provides a summary, focusing on important areas for future research. 


\section{Systemic Risk in Insurance}

The question of the extent to which insurers contribute to systemic risk has generated considerable debate. This lack of consensus is reflected in the academic and policy papers that explore these issues. In this section we briefly review some of the major themes and approaches in this literature and highlight areas where additional research would be valuable. For a comprehensive summary of the literature see Eling and Pankoke's (2014) excellent survey. ${ }^{3}$ The literature we discuss tackles two broad areas: the likelihood that a large insurer experiences material financial distress and, conditional on distress, whether an insurer would transmit stress to other firms or financial markets.

In considering the likelihood that a large insurer might experience significant financial distress, policymakers and researchers have found it useful to try to identify products and business practices that make firms more vulnerable to shocks. Insurance products that make payouts in the event of a death or an accident are unlikely to pose systemic threats because payouts are uncorrelated with financial and economic conditions. Products with these characteristics are sometimes referred to as "traditional" insurance products. However, products and activities with payouts or values that are tied to market conditions may create systemic risk (International Association of Insurance Supervisors (IAIS), 2011 and Geneva Association, 2010). Examples include variable annuities and life insurance policies that guarantee minimum financial performance; products that provide credit guarantees; and capital market activities involving maturity and liquidity transformation. These products are sometimes described as "non-traditional or non-insurance" (NTNI; see IAIS, 2013). Even using the IAIS definition of NTNI, we estimate that $35-40 \%$ of U.S. life insurance liabilities are NTNI and that for the largest U.S. life insurers this share ranges from $40-60 \%$ of liabilities. The precise definition of the terms traditional and NTNI varies across papers, so it is important to dig beyond the labels and consider the underlying potential of a particular activity to make it more likely that an insurer might experience significant financial distress.

Studies have found that "non-traditional" insurance products are risky and can expose insurers in stress situations. Variable annuities (VAs) with guaranteed minimum returns, in particular, are singled-out in this literature. VAs expose insurers to a combination of equity market and interest rate risk. Acharya et al. (2011) points out that insurers with a significant VA book -

\footnotetext{
${ }^{3}$ In the interest of space, we concentrate on papers that study primary insurance. For a discussion of systemic risk as it relates to reinsurance see Cummins and Weiss (2014), van Lelyveld et al. (2011) and Park and Xie (2014).
} 
along with those who sold CDS and mortgage insurance - experienced considerably more stress during the financial crisis. Similarly, Cummins and Weiss (2014), Grace (2011), and Klein (2013) emphasize that VAs could expose insurance companies to shocks during systemic events. Hartley, Paulson and Rosen (2016) provide cross-country evidence that is consistent with the view that guarantees combined with options for policyholders to adjust their behavior can expose life insurers to additional interest rate risk when the interest rate environment evolves in unexpected ways. They show that that interest rate risk among U.S. life insurers, who make heavy use of such guarantees, increased as interest rates decreased to historically low levels in recent years while interest rate risk was roughly unchanged for UK insurers, who are less likely to offer products that combine guarantees with options for policyholders to adjust their behavior.

Others have used AIG's troubles to identify products that can expose insurers to risk. Harrington (2009) argues that CDS underwriting and securities lending caused AIG's financial distress while AIG's insurance operating companies stayed healthy even during the crisis. McDonald and Paulson (2015) emphasize that AIG's extensive securities lending activities were done on behalf of its insurance operating subsidies and that securities lending losses meant that several of AIG's insurance subsidiaries would have been insolvent if they had not received funds from the AIG rescue.

Activities that increase leverage and maturity transformation can also increase the likelihood that an insurer experiences financial distress. Koijen and Yogo (2016a) argue that captive reinsurance, a common practice that allows primary insurers to hold less regulatory capital, leads to greater opacity and leverage in the insurance sector and significantly increases the probability of an insurer default. Foley-Fisher, Narajabad and Verani (2015) show certain forms of insurer funding can also be vulnerable to runs. Specifically, they study extendible funding agreement backed notes, a product that involves considerable maturity transformation, and show that a self-fulfilling run on this type of funding developed during the summer of 2007.

Research on determining whether and how distress at a large insurer might influence other firms and markets is somewhat less developed than to the studies of which products and practices expose insurers to risk. ${ }^{4}$ The most established part of this literature uses information

\footnotetext{
${ }^{4}$ In determining whether an insurance firm is systemically important, both the Financial Stability Oversight Council (FSOC) and the Financial Stability Board (FSB) are charged with first assuming that a firm is experiencing material financial distress and then considering whether that distress could pose a threat to financial stability in the U.S. for
} 
from equity prices and credit default swaps to estimate the extent to which an insurer contributes to systemic risk. These papers largely apply techniques developed in Adrian and Brunnermeier (forthcoming), Acharya, Pedersen, Philippon, and Richardson (2012), Huang, Zhou, and Zhu, (2011), Acharya, Engle, and Richardson (2012) and Brownlees and Engle (2012) to large financial firms, including insurers. In general this literature concludes that some insurers have systemic risk that is on par with that for large banks. For example, Acharya, Biggs, Le, Richardson and Ryan (2011) show that the largest U.S. life insurers and one multiline insurer (AIG) rank in the top 20 of a group of the largest 102 financials prior to the financial crisis, according to some market-based measures of systemic risk. Using a variety of systemic risk measures for the height of the crisis, Weiß and Mühlnickel (2014) conclude that several insurers contributed significantly to the instability of the U.S. financial system during the crisis. It is perhaps important to emphasize that their study does not include AIG. Turning to Europe, Engle, Jondeau, and Rockinger (2015) create market based measures of systemic risk for a sample of 196 large European financial institutions from January 1990 through August 2012. The authors find that at the end of their sample period, "banks and insurance firms bear approximately $83 \%$ and $15 \%$ of the systemic risk in Europe, respectively."

A handful of papers use systemic risk measures as a starting point to address other important questions. For example, Chen, Cummins, Viswanathan, and Weiss (2013) use a forward-looking risk neutral measure of systemic risk estimated from CDS premiums and intraday stock prices and then use Granger causality tests to determine whether insurers are a source of systemic risk or its recipient. They find systemic risk linkages going in both directions between banks and insurers. However, after adjusting for heteroskedasticity, the impact of banks on insurers appears to be much stronger than that of insurers on banks. From this they conclude that insurers tend to be on the receiving end of systemic risk rather than a source of systemic risk. They do not report information for specific firms. Cummins and Weiss (2013) estimate systemic risk for a sample of insurance firms and then use regression analysis to identify characteristics that are associated with higher systemic risk measures. They find life insurer group annuities and separate accounts (which are primarily composed of VAs) can contribute to systemic risk. Another way to examine both the vulnerability of a firm and its potential to transmit shocks is to examine how connected it is to other financial firms. Bilio, Getmansky, Lo, Pelizzon (2012) measure the interconnectedness large U.S. banks, insurers, broker/dealers, and hedge funds 
over the period from 1994 to 2008. They find that interconnectedness increased dramatically in the 2000s. During that period, their results suggest that insurance firms were a potential source of systemic risk for banks, broker/dealers and hedge funds. Neale, Drake Schorno and Semann (2012) implement a similar analysis using industry-specific portfolios instead of individual firms. Their findings are largely consistent with Billio, Getmansky, Lo, Pelizzon (2012), but they identify financial guarantors and life insurers as likely causing insurance to be an increased source of systemic risk for other parts of the financial system.

Events during the financial crisis have also been used to identify the systemic importance of insurers. Grace (2011) examines the degree to which seven events during the financial crisis were associated with abnormally high or low returns for AIG, an index of property and casualty insurers, an index of life insurers, an index of financial firms that received funds from the Troubled Asset Relief Program (TARP), and several large insurance firms that either applied for considered applying for TARP funds. Based on this analysis, Grace concludes that AIG was a systemically important company because shocks to AIG are correlated with negative shocks to other firms. Of course, the many market interventions during the crisis period - some directed at the market as a whole and others directed at individual firms -- make it challenging to isolate the impact of a particular event during the crisis or to draw strong conclusions about the systemic importance of an insurance firm or the insurance industry from their experience during the crisis. For example, in response to the crisis, insurance regulators significantly relaxed restrictions on the use of deferred tax assets as a source of regulatory capital and allowed for flexibility in capital charges on residential and commercial mortgage back securities. $^{5}$

\section{Insurers in the Bond Market}

An important way that insurance firms might spread systemic risk to other financial institutions is through the corporate bond market. Since insurers are major players in corporate bond markets, if they respond to a shock by changing their bond market activity (by selling bonds to

\footnotetext{
${ }^{5}$ Becker and Opp (2014) and Merrill, Nadauld, Stulz and Sherlund (2014) study the impact of the reduction in insurance capital charges for RMBS and CMBS. In addition, Koijen and Yogo (2015) show that existing regulation allowed some life insurance companies were able to boost regulatory capital by selling certain life insurance product at less that their economic cost. More generally, Barnes, Bohn, and Martin (2015) show that during the recent financial crisis, many operating insurance companies had capital shortfalls but were helped by, among other things, regulatory actions.
} 
raise cash, for example), this has the potential to disrupt the bond market. Disruptions to a specific financial market such as the bond market can lead to broader disruptions in financial markets (Brunnermeier and Pederson, 2009). There is a rich literature that examines various aspects of insurers' interactions with the corporate bond market. In this section, we provide a selective review of that literature, focusing on potential implications of the findings for systemic risk. Because our interest is in assessing this literature as it pertains to systemic risk, we focus on papers that study insurer actions in secondary bond markets. During a systemic crisis, many bondholders may want to sell from their existing stock and the liquidity available for these secondary market transaction will likely determine whether there is a fire sale and, if so, how big the fire-sale discounts are. Primary issuance of corporate bonds is likely to essentially disappear during a crisis.

There is evidence that trading by insurers can affect bond liquidity (Ellul, et al., 2011) and, in turn, bond liquidity can have a large effect on bond pricing (Lin, Wang, and Wu, 2011; DickNielsen, Feldhütter, and Lando, 2012). This bears on systemic risk since there is evidence that bond market liquidity varies over time (Acharya and Pederson, 2005; Bao, Pan, and Wang, 2011) and the transmission from bond liquidity to bond prices is stronger in stress situations when there is a "flight to liquidity" (Acharya, Amihud, and Bharath, 2013; Bao, Pan, and Wang, 2011; Crotty, 2013).

Insurance regulation affects the corporate bonds insurers hold. U.S. insurance regulators group bonds into buckets based on credit ratings and require insurers to hold more capital against riskier bonds. These capital rules influence the degree of risk that insurers take on in their bond portfolio. Insurance portfolios are systematically biased toward higher yield bonds within each credit rating bucket (Becker and Ivashina, 2015). This behavior is more prominent during economic expansions and among insurance firms with poor corporate governance and for firms where regulatory capital constraints are more binding.

Capital regulation also affects bond trading in ways that might amplify a systemic shock if the shock is accompanied by a wave of corporate bond downgrades. There is some evidence of a significant but temporary decrease in bond prices due to increased sales - that is, a fire sale by insurance companies, likely induced by the higher capital requirement on non-investment grade bonds relative to investment grade bonds (Ellul et al., 2011; Da and Gao, 2010). These effects are largest for bonds with a high probability of regulation-induced selling and during 
periods when the insurance industry is relatively distressed and other potential buyers' capital is scarce (Ellul et al., 2011). ${ }^{6}$

Regulation may also increase the degree to which insurers transmit shocks from one market to another. Interactions between accounting practices and capital regulation influences insurers' incentives to trade bonds, and this has the potential to transmit shocks across otherwise unrelated markets (Ellul et al., 2015). They provide evidence that life insurers and P\&C insurers responded differently to the wave of downgrades that impacted asset-backed securities (ABS) markets between 2007 and 2009, perhaps because life insurers had more flexibility to value speculative grade instruments using historical cost accounting, while P\&C insurers must mark these instruments to market. Life insurers largely continued to hold downgraded securities at historical cost and selectively sold corporate bonds with the highest unrealized gains to improve their capital positions. This behavior was particularly prominent among life insurers that faced regulatory capital constraints and that were heavily exposed to ABS. In contrast, $P \& C$ insurers did not engage in gains trading and instead sold their re-marked ABS holdings.

The role of insurers as strategic liquidity providers is also affected by regulation. Manconi, Massa and Yasuda (2012) study how problems with securitized bonds tied to real estate markets were transmitted to corporate bond markets. The channel that they emphasize is the liquidity needs of mutual funds that held both types of assets. They find that insurance companies, with the exception of a few whose risk based capital levels were close to regulatory minimums, did not make unusual sales of corporate bonds or ABS during the period of their study (the second half of 2007). This may have been because ABS ratings remained largely intact during this period and so insurance capital requirements on the ABS did not increase. However, they also did not find that insurers stepped in to provide liquidity and speculate that capital regulation prohibits them from playing this role. ${ }^{7}$

A common theme in the bond market literature we have reviewed is that insurers play a major role in the bond market and that regulation can potentially amplify insurers' reaction to shocks, including systemic shocks. Thus, it is important to understand in more detail both the role

\footnotetext{
${ }^{6}$ The evidence of fire sales following bond downgrades is not universal. Ambrose, Cai and Helwege, 2012 find that regulatory-induced selling by insurers has no significant price impact, consistent with a deep market where insurers are not revealing private information about a bond when it is sold for regulatory reasons.

${ }^{7}$ While Manconi, Massa and Yasuda (2012) show that problems with mortgage-backed securities (MBS) did not cause insurers to sell corporate bonds, Merrill, et al. (2014) find that insurers did sell MBS at fire sale prices during the financial crisis. This is another indication that events can lead insurers to sell assets - possibly corporate bonds for some shocks - at fire sale prices.
} 
insurers play in bond market liquidity provision on a regular basis and how that role changes with economic conditions, as well as how these are affected by regulation. In the next section of this paper, we provide some preliminary analysis to address these issues.

4. The Relationship Between Bond Purchases by Life Insurance Firms and Liquidity

The literature described above suggests that life insurance firms have the potential to transmit systemic risk through their actions in corporate bond markets. However, this literature does not directly tackle the question of whether or not insurer actions in corporate bond markets are generally stabilizing or destabilizing. Because life insurers own such a large share of corporate bonds - $20 \%$ as of the end of 2014 - the timing and extent of their purchases and sales can have a large effect on market liquidity. We view this as an important area for further study and, in this section, we take a preliminary step towards determining whether insurers are a stabilizing force by asking how their trading activity is related to bond liquidity.

The role of insurers in corporate bond markets is particularly important to understand given the changes in corporate bond markets following the 2008 financial crisis. The inventory of corporate bonds held by dealer banks decreased sharply from a pre-crisis peak of $\$ 418$ billion in mid-2007 to $\$ 102$ billion in the first quarter of 2009 and has not returned to pre-crisis levels. In contrast, overall corporate bond trade volume declined somewhat in 2008 , but has increased markedly following the crisis (see Figure 2). This is important because the secondary market for corporate bonds has historically been a dealer market, meaning that buyers and sellers often traded through dealer banks. The dealer banks would sometimes match buyers and sellers, but would often buy or sell from their own inventory to meet customer demand. However, developments following the financial crisis have brought into question the role that bond dealers have traditionally performed in providing liquidity in the corporate bond market (see Fender and Lewrick, 2015). Since these dealers are primarily banks, the bonds they hold are subject to Basel III rules on capital and liquidity. Basel III increased the amount of capital banks must hold against corporate bonds and imposed liquidity rules that may further increase their cost of holding inventories of corporate bonds. Additionally, in the United States (home of many bond dealers), the so-called "Volcker Rule," a part of the Dodd-Frank Act, limits dealer banks trading corporate bonds for their own gain (proprietary trading). As the volume of investment-grade corporate bond trading recovered markedly from the financial crisis, increasing from $\$ 7.8$ trillion in 2007 to $\$ 15.2$ trillion in 2014 , dealer inventories remained 
persistently low, averaging \$140 billion from 2009-2015 (see Figures 1 and 2 ). ${ }^{8}$ In addition, the share of corporate bonds held by mutual funds and ETFs has been increasing (Adrian, Fleming, Sharchar, Vogt, 2015). These changes may have affected overall bond market liquidity and as well as altered the role insurers play in this market.

While life insurance firms are among the largest owners of corporate bonds, they are not generally thought to be the most active traders (see, e.g., Massa, Yasuda, and Zhang, 2012). We confirm this using data from TRACE, Mergent, and insurance regulatory findings. ${ }^{9}$ In our sample, which runs from 2005 to 2014, life insurance companies use the secondary market to sell $16.2 \%$ and buy $20.3 \%$, by par value, of their corporate bond holdings every year. ${ }^{10}$ This turnover rate is lower than the turnover rate for all corporate bonds, which is $83.9 \%$ per year over our sample period. ${ }^{11}$ Figure 3 compares the aggregate turnover of investment grade corporate bonds to similar measures for life insurer purchases and sales of investment grade corporate bonds. Aggregate turnover and life insurer sales both peak in 2009, providing one indicator of the role that life insurers might play in the corporate bond markets.

We explore the role of life insurers in the corporate bond market in stages. First, we examine how life insurer trading in the secondary market varies with bond liquidity. Since these trades may be a function of bond specific characteristics that do not affect liquidity, our second stage is to look at whether insurers purchase more of a given bond when that bond has less liquidity than typical. Finally, we take a step toward looking how insurer bond trading is affected by market-wide liquidity. In all of this, our focus is on the net effect of the liquidity of the bond market or an individual bond issue on insurers, so we examine the net purchases of the insurance industry as a whole. In order to see whether net purchases are changing because of purchase or sale activity, we also examine how gross secondary market bond purchases and gross bond sales by life insurance firms are affected by liquidity. ${ }^{12}$

Life insurer trading activities can affect bond market conditions if it varies with the liquidity of individual bonds or with overall market liquidity. Life insurers tend to purchase the most liquid

\footnotetext{
${ }^{8}$ Patterns are similar for high yield bonds. We focus on investment grade corporate bonds as insurers are most active in this market.

${ }^{9}$ The regulatory data comes from SNL Financial.

${ }^{10}$ We define a transaction as taking place on the secondary market if it occurs at least six months after a bond is issued.

${ }^{11}$ The turnover rate for all corporate bonds is computed as the volume of sales from TRACE divided by total corporate bonds outstanding at the end of the prior year from the Flow of Funds data.

${ }^{12}$ Purchases and sales are the total gross purchases and sales of all life insurance firms so if one insurance firm sells a bond to another life insurer, both the purchase and sale are counted.
} 
bonds in the secondary market. To see this, we take investment grade bonds and rank all bondyear observations by one measure of liquidity, turnover (par value of transaction per year per dollar of bond outstanding), and then divide the sample into quartiles. ${ }^{13}$ Each turnover quartile has approximately the same par value of bonds outstanding. Over one-half of all bonds purchased (on the secondary market) by life insurers are in the top quartile ranked by turnover (see Table 1). This is not surprising given that these bonds are probably the easiest to purchase with short notice. However, insurer purchases tend to be a larger share of overall volume for the less liquid bonds. Life insurer purchases comprise $5 \%$ of the total trade volume for each of the two highest quartiles but over $30 \%$ for the quartile with the lowest turnover. This is a sign that insurers are providing more liquidity for the least liquid bonds. On the other side of the transaction, life insurers sell roughly the same volume of bonds in each quartile. This could signal that insurer sales are at least somewhat independent of a bond's liquidity. It may also mean that insurers are not trying to dump illiquid bonds. However, to draw firmer conclusions we need to control for bond and market characteristics.

The timing of purchases by life insurers is an important part of understanding their role in bond markets. Life insurers are always in the market for new assets as they typically have a relatively constant flow of premiums to invest. In addition, they have some flexibility in how they allocate their portfolio. For example, they can allocate more to bonds and less to other assets or they can allocate more to bonds with certain characteristics. This allows them to change their net purchases of corporate bonds, and their choice of which bonds to focus on, as a function of market conditions. In particular, life insurers can enhance liquidity - and potentially absorb systemic risk - if they are more likely to purchase a bond when the bond has low liquidity. To investigate this, we estimate the following equation:

$$
\frac{T R_{i t}}{O_{i t}}=\alpha_{1}+\beta_{1} l i q_{i t}+\sum_{t} \gamma_{t} Y_{t}+\delta_{1 i} B_{i}+\varepsilon_{i t}
$$

This equation relates the trades by the insurance industry $\left(T R_{i t}\right)$ as a fraction of par value outstanding $\left(O_{i t}\right)$ for corporate bond $i$ during year $t$ to an estimate of the liquidity of that bond $\left({ } i q_{i t}\right)$ in year $\mathrm{t}$. We examine three outcome variables: net purchases, gross purchases, and gross sales. We include time dummies $Y_{t}$ to control for changes in overall bond market conditions. Bond fixed effects $-B_{i}$ is an indicator variable that is one for bond $i$ and zero otherwise - control for the tendency of insurance purchases to be concentrated among bonds with characteristics,

\footnotetext{
${ }^{13}$ We explain why we use turnover as a measure of liquidity below.
} 
including credit quality, which may be correlated with their liquidity. Thus, the coefficient on liquidity, $\beta_{1}$, measures changes in trades relative to the average trading for a given bond when that bond's liquidity changes.

We are also interested in how the relationship of life insurers' corporate bond trading patterns to liquidity is affected by general market liquidity and, specifically, whether the financial crisis or the recent changes in the bond market affect insurer trading behavior. To examine this, we allow the effect of liquidity on insurer trading to vary over:

$$
\frac{T R_{i t}}{O_{i t}}=\alpha_{2}+\sum_{t} \beta_{2 t} l i q_{i t} Y_{t}+\sum_{t} \gamma_{t} Y_{t}+\delta_{2 i} B_{i}+\varepsilon_{i t}
$$

Where, again, trades can be net purchases, gross purchases, or gross sales.

We measure liquidity in two ways that we believe capture different aspects of the ability to trade a bond. Each measure has strengths and weaknesses which we outline below.

Traditionally, liquidity is measured using price impact, bid-ask spread, and depth. It is difficult to measure these accurately for corporate bonds. Bonds are traded in over-the-counter markets and bids and offers are not publicly available. In addition, many bonds trade only few times a day, if at all. However, bond trades, along with some information on trade size, are available from the TRACE data. ${ }^{14}$ The paucity of information on potential bond trades (i.e., bids and offers) has led researchers to estimate bond liquidity in a variety of ways. Many of these involve trying to back out an effective bid-ask spread or, equivalently, the round-trip cost of buying and selling the bond. There is evidence that the different liquidity measures of this type are highly correlated (Schestag, Schuster, and Uhrig-Homburg, 2015), so we select one. Ours is based on the approach in Amihud (2002) which measures the price impact of a trade per unit traded. For each bond, we construct a price impact for each trade after the first one in a day. The price impact for trade $j(j>1)$ of bond $i$ on day $d$ is:

$$
A_{i d j}=\frac{\frac{\left|P_{j}-P_{j-1}\right|}{P_{j}-1}}{Q_{j}}
$$

\footnotetext{
${ }^{14}$ TRACE includes trade size up to $\$ 5$ million and a dummy for all trades above $\$ 5$ million. Enhanced TRACE, which we use, also includes trade size for all trades above $\$ 5$ million but is only available with a lag. For our sample, we have enhanced TRACE for 2005-to 2013. For 2014 we use (unenhanced) TRACE and, as necessary, we estimate the trade size for trades over $\$ 5$ million on a bond-by-bond basis using information from enhanced TRACE for earlier years.
} 
where $P_{j}$ is the price for trade $j$ and $Q_{j}$ is the par value of the bond for trade $j$. The daily price $\operatorname{impact} A_{i d}$ is the median value of $A_{i d j}$ for day $d$. Our Amihud-based measure, Amihud $d_{i t}$, for bond $i$ in year $t$ is the median of the daily measures $A_{i d}$ for all days on which there were at least two trades. Thus, Amihud is a measure of illiquidity not liquidity. We only include observations for bonds with at least 10 daily price impact measures in a given year. Since the Amihud measure captures illiquidity, when we use it in the equations above, a positive coefficient on the Amihud measure in our regressions indicates that the insurance industry tends to trade more when bonds are illiquid.

In addition to only being available for bonds with sufficient trades, the magnitude of the Amihud-based measure depends on the identity of the buyer and the seller. Bondholders that trade in larger dollar amounts pay smaller markups (O'Hara, Wang, and Zhou, 2015). This may mean that our Amihud measure captures trades among different types of bondholders and, thus, may not be a pure price impact indicator. For this reason, we only include transactions of at least $\$ 100,000$ in constructing our Amihud measure. As an indication of why this is important, the mean value of Amihud in our sample is $0.56 \%$. If we use the same bond-year observations but include all trades rather than just those above $\$ 100,000$, the Amihud measure has a mean of $16.48 \%$. This is consistent with smaller trades having a substantially larger markup. Since the markup differences are likely based on market power, not information about the liquidity of the bond, we choose to exclude small trades when calculating Amihud. ${ }^{15}$ The Amihud measure still compares trades of very different sizes, ranging from $\$ 100,000$ to over $\$ 25$ million. We could further narrow the range of trade sizes we consider but this would reduce the size of our sample significantly.

The limitations of the Amihud measure lead us to also estimate an alternative measure of liquidity. Since bond trading information is publicly available, we include turnover as a second measure of liquidity. Turnover is an indirect measure of liquidity. We expect that the price impact of selling a bond that has more trading volume is smaller than the price impact of selling a bond that has less trading volume. Therefore, turnover is correlated with liquidity. Although turnover captures liquidity indirectly, it does not suffer from the measurement issues associated with the lack of data on bids and offers nor is it likely to be distorted by the characteristics of the buyer and the seller like other measures of liquidity, including Amihud. We define turnover $r_{i}$, as the ratio of the par value of transactions during year $t$ to the par value

${ }^{15}$ Excluding small trades also reduces concerns that the Amihud measure may have a time trend related to the growth in retail participation in corporate bond markets. 
outstanding for bond $\mathrm{i}$ in year $\mathrm{t}$. Turnover is not subject to noise from differences in bid-ask spreads, so we include all trades (including those smaller than $\$ 100,000$ ) when computing it. We estimate our regression models using both Amihud and turnover as liquidity measures. Since we suspect that the two measures capture different aspects of liquidity, our preferred specifications include both liquidity measures. Note that higher turnover indicates greater liquidity, so in the equations above, a negative coefficient on turnover indicates that the insurance industry tends to trade more when bonds are illiquid.

We restrict our attention to investment grade bonds as they form the bulk of life insurer portfolios. This also allows us to minimize the potential impact of ratings downgrades which may pressure insurers to sell for regulatory reasons as discussed above (Ellul, et al., 2011). We also require bonds to be in the sample for a minimum of three years. The estimation sample covers the period from 2005 to 2014. It includes 5,301 individual bonds and 28,495 bond-year observations. On average, bonds in the sample have \$741 million outstanding, an initial maturity of 13.9 years, and have 1,260 trades per year of which $28 \%$ are over $\$ 100,000$ (Table 2). The mean values for Amihud and turnover are $0.56 \%$ and $76.7 \%$, respectively.

With the exception of 2006 and 2008, life insurance firms are net sellers on the secondary market for investment grade corporate bonds (Figure 2). For the average bond in our sample sales also exceed purchases. For a given bond, insurers are net sellers of $1.3 \%$ of the amount outstanding for a bond in a year (Table 2). This is a result of insurance purchases of $2.3 \%$ and sales of $3.6 \%$ of the amount outstanding, on average. Overall, insurers total bond holdings are generally increasing and they do most of their purchasing in the primary market.

The baseline results examining how life insurers' secondary market net corporate bond trades vary with bond liquidity are presented in the first three columns of Table 3 . The results come from estimates of equation [1]. As shown in the first column, the estimated coefficient on turnover is -0.38 . This indicates that life insurers purchase more of a bond issue when the issue has relatively low liquidity as measured by turnover. If a bond's turnover decreased by one standard deviation (68.5\%), we estimate that insurers would increase their net purchases by $26.7 \%$ which is one-third of mean turnover in the sample. Changes in Amihud have no significant effect on net purchases. The estimated coefficient on Amihud, as shown in the second column is not significantly different from zero. This may hide differences across time, something we explore below. Note that the coefficients on turnover and Amihud are very similar in the regressions where they appear alone and in the regression where they are both 
included. This suggests that they are picking up difference aspects of liquidity. This same pattern is found in all of the estimates so, to save space, we report results only for estimates that include both turnover and Amihud.

The evidence indicates that life insurers, on net, purchases bonds when the bonds have lower than average liquidity. The final two columns of Table 3 present the results for regressions with gross purchases and sales as the dependent variable. Insurers are more likely to purchase bonds when they have low turnover and low Amihud and to sell them when they have high turnover and (weakly) high Amihud. This gives further support to the hypothesis that turnover and Amihud are measuring different aspects of liquidity.

Over our sample period, corporate bond liquidity conditions changed - due to the financial crisis in 2008 and 2009 and possibly in later years because of the low interest rate environment and the changes in the market making behavior of dealer banks. So, while the results in Table 3 suggest that life insurance firms tend to buy more of a given bond when it is more illiquid than is typical, we are also interested in how this behavior may have changed over time. Table 4 and Figure 4 report the results of estimating equation [2], where the coefficients on the liquidity variables are allowed to vary at an annual frequency. These estimates indicate that there have been some changes in the sensitivity of life insurers' net bond purchases to liquidity over time.

The sensitivity of life insurers' corporate bond trading activity to turnover from 2005 to 2014 can be divided into three regimes. In the first regime, $2005-2008$, the coefficients on turnover in the net purchases regression were becoming less negative (Figure 4). Then, from 2009-2012 - that is, the start of the period of low interest rates - the coefficients were essentially zero. The third regime starts when there was another break in 2013. This is best seen by focusing on gross purchases and sales. Life insurers went from both buying and selling more of a bond when it was more liquid - that is, when turnover was high - at the start of the sample to buying and selling more of a bond when it was less liquid in 2012. In aggregate, net purchases were generally more sensitive to bond liquidity from 2009-2012 (regime 2) than they were in 2005-2008 (regime 1). For example, the coefficient on turnover, $\beta_{2}$, in the net purchase regression went from -1.23 in 2005 to -0.03 in 2012 (column 1 of Table 4). This means that in 2005 , the insurance industry reduced the net purchases of a bond by 1.23 basis points (or about $1 \%$ of the mean for all bonds in the sample) for each 1 percentage point increase in a bond's turnover but by 2012, there was essentially no relationship between the two variables (the predicted 0.03 basis point change per 1 percentage point increase in turnover is not statistically 
significant) But something changed in 2013. The coefficients on turnover for the gross purchases and sales estimates went from negative and significant in 2012 (-0.77 and -0.75, respectively) to positive and significant in 2013 and 2014 (for 2013, 1.58 and 0.46, respectively) meaning that insurers went from being more likely to both purchase and sell bonds when the bonds were less liquid than average to being less likely to both purchase and sell bonds when the bonds were less liquid than average. The net effect of these changes was to push the coefficient on turnover for the net purchase regression up to 1.17 in 2013 although it returned to essentially zero in 2014. By allowing the coefficients to vary over time, we see that the insignificant coefficient on the Amihud measure in Table 3 hid a systematic change over time. During the sample period, the coefficients on Amihud in the net purchase regressions increased steadily from -209.5 in 2005 to 133.9 in 2014 (column 1 of Table 4). This change substantially affected the predicted response of net purchases to changes in Amihud liquidity. In 2005, a one standard deviation increase in Amihud-which represents a decrease in liquidity - decreased net purchases by 1.6 percentage points, or 0.25 standard deviations. By 2012, the same one standard deviation increase in Amihud resulted in a 1.1 percentage points, or a 0.16 standard deviation increase, in net purchases. These results indicate that life insurers moved toward purchasing bonds with relatively lower levels of liquidity over time. While the Amihud coefficients for the gross purchase regressions were increasing over time (column 2 of Table 4) and they were decreasing for the sales regressions (column 3 of Table 4), the net purchase results were largely due to the change in sales activity.

Overall, the regression results suggest that life insurers tend to systematically absorb liquidity risk by purchasing more of a bond when its liquidity is relatively low. However, the sensitivity of trading to bond liquidity has changed over time. Determining the causes of the changes is difficult. There were a number of things going on at once. The financial crisis occurred in 2008, which affected corporate bonds directly. In addition, the regulatory and legal responses to the crisis may have affect bond trading as well. During the crisis, long-term interest rates decreased rapidly. They remained at or near historically low levels through the end of the sample period. In addition, as mentioned above, the dealer banks that intermediated corporate bond sales sharply reduced their bond inventories following the crisis. These factors may have influenced the sensitivity of life insurance net purchases to liquidity. Still, the change in the sensitivity of life insurer trading in 2013, as insurers began to plan for a potentially extended period of low interest rates, suggests there may be insurance industry specific factors at play as well. 
It is difficult to draw firm conclusions about the systemic role of life insurers in the corporate bond market from this analysis. By purchasing bonds when the bonds' liquidity is below average, life insurers can make it easier for firms - including other insurers - to sell bonds. This may reduce the chance of fire sales in corporate bond markets - at least ones prompted by events outside the insurance industry. However, the finding that insurers are generally more likely to buy less liquid bonds opens up the possibility that a shock to the industry might disrupt this pattern with broader implications for bond market liquidity. We do not find any evidence that insurers stepped to increase bond purchases specifically during the financial crisis. In fact, in 2009 aggregate insurer secondary sales far exceeded their secondary purchases (Figure 2). The estimated coefficients presented in Figure 4 suggest that, in other ways, the financial crisis did not substantially disturb the trends in the relationship between insurer bond purchases and bond liquidity. Insurer bond purchases were largely independent of bond liquidity in 2009, whether measured by turnover or Amihud. Thus, it is not clear whether life insurers would play a stabilizing role in a future systemic crisis.

5. Summary and future directions

The literature that we have reviewed does not yet provide a satisfactory answer to the important question of whether the insurance industry poses systemic risk. The financial crisis is both a blessing and a curse for researchers interested in evaluating this for the insurance industry. On the one hand, it provides a real world example of a financial crisis and one can examine how insurance firms behaved and how they fared during this period. On the other hand, the crisis was accompanied by a wealth of financial market and regulatory interventions aimed at insurers and at the broader financial sector. These interventions helped stabilize the insurance sector (Barnes, Bohn, and Martin, 2015; Becker and Opp, 2014; Merrill, Nadauld, Stulz, and Sherlund, 2014). Still, there is evidence that large insurers - potentially because of a handful of activities such as variable annuities and underwriting CDS - may contribute to systemic risk.

A fruitful avenue for future research is to consider possible mechanisms through which shocks to the insurance industry might be spread to other parts of the financial system. We have taken a first step by analyzing the relationship between insurance bond purchases and bond 
liquidity. Our analysis shows that life insurers are more likely to purchase a bond when that bond is relatively illiquid. This suggests that insurers provide liquidity to bond markets.

However, our analysis is not powerful enough to determine whether insurers are more likely to step in during a period of extreme stress. There remains much to be done, both in terms of refining the analysis of bond market interactions and in exploring other avenues. For example, in analyzing bond market interactions, taking into account insurer financial strength would be useful as would more directly analyzing the evolution of corporate bond market making and the importance of insurers as a potential source of liquidity. In terms of considering other avenues by which insurers may transmit or mitigate systemic risk, an important area for future research is deepening our understanding of how changes in policyholder behavior flow through to insurers. Policyholders cannot run on a life insurer in the same way as depositors can run on a bank, but there are some insurance liabilities which can be withdrawn from insurers (Berends, McMenamin, Plestis, and Rosen, 2013). We still need to understand the risk of an insurance 'walk' and whether one could pose a systemic threat. In addition, the potential contribution of other areas such as the insurance state guarantee system (Cummins and Weiss, 2014; Koijen and Yogo, 2016b) and captive reinsurance (Koijen and Yogo, 2016a) to systemic risk are fruitful areas for future research. 


\section{References}

Acharya, V. V., Y. Yakov, and S. T. Bharath (2013): "Liquidity Risk of Corporate Bond Returns: A Conditional Approach," Journal of Financial Economics.

Acharya, V. V., R. Engle, and M. Richardson (2012): "Capital shortfall: A New Approach to Ranking and Regulating Systemic Risks," American Economic Review 102(3): 59-64.

Acharya, V. V., J. Biggs, H. Le, M. Richardson, and S. Ryan (2011): "Systemic Risk and The Regulation of Insurance Companies," in V. V. Acharya, T. F. Cooley, M. Richardson, and I. Walter (Eds.) Regulating Wall Street-The Dodd-Frank Act and the New Architecture of Global Finance, Hoboken: John Wiley \& Sons, pp. 241-301.

Acharya, V.V., and L. Pedersen (2005): “Asset Pricing with Liquidity Risk," Journal of Financial Economics, 77(2): $375-410$.

Acharya, V. V., L. Pederson, T. Philippon, and M. Richardson (2012): “Measuring Systemic Risk," Working Paper, New York University, New York, NY.

Adrian, T., and M. K. Brunnermeier (forthcoming): "CoVaR," American Economic Review, forthcoming.

Adrian, T., M. Fleming, O. Shachar and E. Vogt (2015): “Redemption Risk of Bond Mutual Funds and Dealer Positioning," Liberty Street Blog, Federal Reserve Bank of New York. Available here: http://libertystreeteconomics.newyorkfed.org/2015/10/redemption-risk-of-bond-mutual-fundsand-dealer-positioning.html\#.Vri7IXIUV8Q

Ambrose, B. W., K. N. Cai and J. Helwege (2012): "Fallen Angels and Price Pressure," Journal of Fixed Income, 21(3): 74-86.

Amihud, Y. (2002): "Illiquidity and Stock Returns: Cross-Section and Time-Series Effects," Journal of Financial Markets, 5(1): $31-56$.

Bao, J., J. Pan and J. Wang (2011): "The Illiquidity of Corporate Bonds," The Journal of Finance, 66: 911946.

Barnes, M. L., J. Bohn, and C. L. Martin (2015): "A Post-Mortem of the Life Insurance Industry's Bid for Capital during the Financial Crisis," Federal Reserve Bank of Boston Current Policy Perspectives, 15-8.

Becker, B. and V. Ivashina (2015): "Reaching for Yield in the Bond Market," The Journal of Finance, 70: 1863-1902.

Becker, B. and M. Opp (2014): "Regulatory Reform and Risk-Taking: Replacing Ratings," NBER Working Paper.

Berends, K., R. McMenamin, T. Plestis, and R. J. Rosen (2013): "The Sensitivity of Life Insurance Firms to Interest Rate Changes," Economic Perspectives, Federal Reserve Bank of Chicago, Chicago, IL.

Berry-Stölzle, T. R., G. P. Nini, and S. Wende (2014): "External Financing in the Life Insurance Industry: Evidence from the Financial Crisis," Journal of Risk and Insurance, 81(3): 529-562. 
Billio, M., M. Getmansky, A. W. Lo, and L. Pelizzon (2012): "Econometric Measures of Connectedness and Systemic Risk in the Finance and Insurance Sectors," Journal of Financial Economics, 104(3): 535-559.

Brownlees, C., R. Engle (2012): "SRISK: A Conditional Capital Shortfall Measure of Systemic Risk," Working Paper.

Brunnermeier, M. and L. H. Pedersen (2009): "Market Liquidity and Funding Liquidity," Review of Financial Studies, 22: 2201-2238.

Chen, H., J.D. Cummins, K.S. Viswanathan, and M. A. Weiss (2013): "Systemic Risk and the Interconnectedness between Banks and Insurers: An Econometric Analysis," Journal of Risk and Insurance, 81(3): 623-652.

Crotty, K. (2013): “Corporate Yield Spreads and Systemic Liquidity," Working Paper.

Cummins, J. D., and M.A. Weiss (2013): "Systemic Risk and Regulation of the U.S. Insurance Industry," Working Paper, Temple University, Philadelphia, PA.

Cummins, J. D., and M.A. Weiss (2014): "Systemic Risk and the U.S. Insurance Sector," Journal of Risk and Insurance, 81(3): 489-528.

Da, Z., and P. Gao (2010): "Clientele Change, Persistent Liquidity Shock, and Bond Return Reversal After Rating Downgrades," Journal of Financial and Quantitative Analysis, 45(1): 27-48.

Dick-Nielsen, J., P. Feldhütter, D. Lando (2012): “Corporate Bond Liquidity Before and After the Onset of the Subprime Crisis," Journal of Financial Economics, 103(3): 471-492.

Eling, M. and D. Pankoke (2014): "Systemic Risk in the Insurance Sector: Review and Directions for Further Research," Working Paper, University of St. Gallen.

Ellul, A. and C. Jotikasthira and C. T. Lundblad (2011): "Regulatory Pressure and Fire Sales in the Corporate Bond Market," Journal of Finance, 101: 596-620.

Ellul, A. and C. Jotikasthira, C. T. Lundblad and Y. Wang (2015): "Is Historical Cost Accounting a Panacea? Market Stress, Incentive Distortions and Gains Trading," Journal of Finance, forthcoming.

Engle, R., E. Jondeau, and M. Rockinger (2015): "Systemic risk in Europe," Review of Finance, forthcoming.

Fender, I. and U. Leqrick (2015): "Shifting Tides - Market Liquidity and Market-Making in Fixed Income Instruments," BIS Quarterly Review, 97-109.

Foley-Fisher, N.,B. Narajabad, S. Verani (2015): "Self-Fulfilling Runs: Evidence from the U.S. Life Insurance Industry," Working Paper.

Geneva Association (2010): "Systemic Risk in Insurance-An Analysis of Insurance and Financial Stability," International Association for the Study of Insurance Economics.

Grace, M. F. (2011): "The Insurance Industry and Systemic Risk: Evidence and Discussion," Working Paper, Georgia State University, Atlanta, GA. 
Harrington, S. E. (2009): "The Financial Crisis, Systemic Risk, and the Future of Insurance Regulation," Journal of Risk and Insurance, 76(4): 785-819.

Hartley, D., Paulson, A.L., R.J. Rosen (2016): “Measuring Interest Rate Risk in the Life Insurance Sector: the U.S. and the U.K.," The Economics, Regulation, and Systemic Risk of Insurance Markets, Oxford: Oxford University Press, forthcoming.

Huang, X., H. Zhou, and H. Zhu (2011): "Systemic Risk Contributions," Working Paper, Finance and Economics Discussion Series, Divisions of Research \& Statistics and Monetary Affairs, Federal Reserve Board, Washington, D.C.

IAIS (2011): Insurance and Financial Stability.

IAIS (2013): Global Systemically Important Insurers: Policy Measures.

Klein, R. W. (2013) "Insurance Market Regulation: Catastrophe Risk, Competition and Systemic Risk," Handbook of Insurance, New York: Springer, 2: 909-939.

Koijen, R. S. J., and M. Yogo (2015): "The Cost of Financial Frictions for Life Insurers," American Economic Review, 105(1), 2015, p.445-475.

Koijen, R. S. J., and M. Yogo (2016a): "Shadow Insurance," Econometrica, forthcoming.

Koijen, R. S. J., and M. Yogo (2016b): "Risks of Life Insurers: Recent Trends and Transmission Mechanisms," The Economics, Regulation, and Systemic Risk of Insurance Markets, Oxford: Oxford University Press, forthcoming.

Lin, H., J. Wang, C. Wu (2011): “Liquidity Risk and Expected Corporate Bond Returns," Journal of Financial Economics, 99: 628-650.

Manconi, A., M. Massa, and A. Yasuda (2012): "The Role of Institutional Investors in Propagating the Crisis of 2007-08," Journal of Financial Economics, 104: 491 - 518.

Massa, M., A. Yasuda and L. Zhang (2012): "Supply Uncertainty of the Bond Investor Base and the Leverage of the Firm," Journal of Financial Economics, 110: 185-214.

McDonald, R. L. and A.L. Paulson (2015): “AIG in Hindsight," Journal of Economic Perspectives.

Merrill, C. B., T. D. Nadauld, R. M. Stulz, and S. M. Sherlund (2014): "Were there Fire Sales in the RMBS Market?" Working Paper.

Odell, K. A., M.D. Weidenmier (2004): "Real Shock, Monetary Aftershock: The San Francisco Earthquake and the Panic of 1907," Journal of Economic History, Vol. 64: 1002-1027.

O'Hara, M., Y. Wang, and X. Zhou (2015): “The Best Execution of Corporate Bonds," Working Paper.

Park, S. C., and X. Xie, X (2014): "Reinsurance and Systemic Risk: The Impact of Reinsurer Downgrading on Property-Casualty Insurers," Journal of Risk and Insurance, 81(3): 587-622.

Neale, F.R., P. P. Drake, P. Schorno, and E. Semann (2012): "Insurance and Interconnectedness in the Financial Services Industry." 
Rose, J. D. (2016). "The Resolution of a Systemically Important Insurance Company during the Great Depression," Finance and Economics Discussion Series 2016-005. Washington: Board of Governors of the Federal Reserve System,

Schestag, R., P. Schuster, and M. Uhrig-Homburg (2015): "Measuring Liquidity in Bond Markets," Working Paper.

Van Lelyveld, I., F. Liedorp, and M. Kampman (2011): “An Empirical Assessment of Reinsurance Risk," Journal of Financial Stability, 7(4): 191-203.

Weiß, G. N. F., and J. Mühlnickel (2014): “Why Do Some Insurers Become Systemically Relevant?” Journal of Financial Stability, 13: 95-117. 
Table 1. Trades of investment grade bonds by life insurers, 2005-2014.

\begin{tabular}{|l|c|c|c|c|}
\hline Turnover Quartile & $\begin{array}{c}\text { Life Net Purchases } \\
(\$ \mathrm{~B})\end{array}$ & $\begin{array}{c}\text { Life Purchases } \\
(\$ \mathrm{~B})\end{array}$ & $\begin{array}{c}\text { Life Sales } \\
(\$ \mathrm{~B})\end{array}$ & $\begin{array}{c}\text { Trade Volume } \\
(\$ \mathrm{~B})\end{array}$ \\
\hline Q1 (High) & 676.6 & 948.9 & 272.4 & $17,509.1$ \\
\hline Q2 & 17.9 & 369.4 & 351.5 & $7,224.7$ \\
\hline Q3 & -31.0 & 272.3 & 303.3 & $3,726.1$ \\
\hline Q4 (Low) & 55.7 & 276.5 & 220.8 & $1,257.4$ \\
\hline
\end{tabular}

Turnover quartiles are set to have as close to the same dollar value per quartile as possible. A bond is in quartile $q$ in year $t$ if its turnover is in the $q^{\text {th }}$ quartile for the sample in that year. Trade volume is for all trades in TRACE, not just those by life insurance firms.

Source: Authors' calculations based on data from SNL Financial, TRACE, and Mergent.

Table 2. Summary statistics.

\begin{tabular}{|l|c|c|c|}
\hline Variable & Mean & Median & Std Dev. \\
\hline Amihud & $0.56 \%$ & $0.30 \%$ & $0.81 \%$ \\
\hline Turnover & $76.7 \%$ & $55.1 \%$ & $68.5 \%$ \\
\hline Net Purchases (\% of Amt. Out.) & -1.3 & -0.2 & 6.7 \\
\hline Gross Purchases (\% of Amt. Out.) & 2.3 & 0.8 & 4.2 \\
\hline Sales (\% of Amt. Out.) & 3.6 & 1.8 & 5.7 \\
\hline Years in sample & 6.2 & 6.0 & 2.2 \\
\hline Amount Outstanding (\$M) & 741.4 & 500.0 & 624.0 \\
\hline \# of trades per year & 1260.1 & 636.8 & 1746.3 \\
\hline \# of trades over \$100K per year & 350.9 & 207.2 & 399.1 \\
\hline Initial maturity, in years & 13.9 & 10.0 & 9.7 \\
\hline
\end{tabular}

The sample has 28,576 bond-year observations from the period 2005-2014.

Source: Authors' calculations based on data from SNL Financial, TRACE, and Mergent. 
Table 3. Estimates of life insurer bond activity as a function of bond liquidity.

\begin{tabular}{|c|c|c|c|c|c|}
\hline & (1) & (2) & (3) & (4) & (5) \\
\hline & $\begin{array}{c}\text { Net } \\
\text { Purchases }\end{array}$ & $\begin{array}{c}\text { Net } \\
\text { Purchases }\end{array}$ & $\begin{array}{c}\text { Net } \\
\text { Purchases }\end{array}$ & $\begin{array}{c}\text { Gross } \\
\text { Purchases }\end{array}$ & Sales \\
\hline \multirow[t]{2}{*}{ Turnover } & $-0.38 * * *$ & & $-0.40 * * *$ & $-0.20 * * *$ & $0.20 * * *$ \\
\hline & $(0.087)$ & & $(0.088)$ & $(0.063)$ & $(0.060)$ \\
\hline \multirow[t]{2}{*}{ Amihud $^{*} 100$} & & -16.58 & -19.02 & $-13.15^{* * *}$ & 2.97 \\
\hline & & $(14.021)$ & $(14.055)$ & $(5.025)$ & $(10.821)$ \\
\hline \multirow[t]{2}{*}{$Y_{2006}$} & $-1.99 * * *$ & $-1.95 * * *$ & $-1.99 * * *$ & $-1.44 * * *$ & $0.53 * * *$ \\
\hline & $(0.205)$ & $(0.205)$ & $(0.205)$ & $(0.155)$ & $(0.174)$ \\
\hline \multirow[t]{2}{*}{$Y_{2007}$} & $-2.25^{* * *}$ & $-2.13^{* * *}$ & $-2.24 * * *$ & $-1.27 * * *$ & $1.08 * * *$ \\
\hline & $(0.282)$ & $(0.276)$ & $(0.282)$ & $(0.212)$ & $(0.176)$ \\
\hline \multirow[t]{2}{*}{$Y_{2008}$} & $-3.24 * * *$ & $-2.97 * * *$ & $-3.12 * * *$ & $-2.63 * * *$ & $0.63 * * *$ \\
\hline & $(0.204)$ & $(0.231)$ & $(0.231)$ & $(0.154)$ & (0.198) \\
\hline \multirow[t]{2}{*}{$Y_{2009}$} & $-4.09 * * *$ & $-3.79 * * *$ & $-3.91 * * *$ & $-2.39 * * *$ & $1.43 * * *$ \\
\hline & $(0.284)$ & $(0.296)$ & $(0.295)$ & $(0.157)$ & $(0.239)$ \\
\hline \multirow[t]{2}{*}{$Y_{2010}$} & $-3.86 * * *$ & $-3.65 * * *$ & $-3.79 * * *$ & $-3.30 * * *$ & $0.52 * * *$ \\
\hline & $(0.213)$ & $(0.223)$ & $(0.222)$ & $(0.148)$ & $(0.190)$ \\
\hline \multirow[t]{2}{*}{$Y_{2011}$} & $-4.72 * * *$ & $-4.47 * * *$ & $-4.68 * * *$ & $-4.10 * * *$ & $0.63 * * *$ \\
\hline & $(0.208)$ & $(0.209)$ & $(0.212)$ & $(0.146)$ & $(0.184)$ \\
\hline \multirow[t]{2}{*}{$Y_{2012}$} & $-6.23 * * *$ & $-5.89 * * *$ & $-6.20 * * *$ & $-4.08 * * *$ & $2.15^{* * *}$ \\
\hline & $(0.222)$ & $(0.215)$ & $(0.224)$ & $(0.150)$ & (0.195) \\
\hline \multirow[t]{2}{*}{$Y_{2013}$} & $-6.34 * * *$ & $-5.93 * * *$ & $-6.34 * * *$ & $-4.39 * * *$ & $1.99 * * *$ \\
\hline & $(0.240)$ & $(0.220)$ & $(0.240)$ & $(0.155)$ & $(0.208)$ \\
\hline \multirow[t]{2}{*}{$Y_{2014}$} & $-6.94 * * *$ & $-6.49 * * *$ & $-6.96 * * *$ & $-5.08 * * *$ & $1.92 * * *$ \\
\hline & $(0.255)$ & $(0.227)$ & $(0.254)$ & $(0.158)$ & $(0.222)$ \\
\hline \multirow[t]{2}{*}{ Constant } & $3.45^{* * *}$ & $2.98 * * *$ & $3.53^{* * *}$ & $5.72 * * *$ & $2.18^{* * *}$ \\
\hline & $(0.208)$ & $(0.176)$ & $(0.211)$ & $(0.152)$ & (0.173) \\
\hline Bond Fixed Effects & Yes & Yes & Yes & Yes & Yes \\
\hline Observations & 28,576 & 28,576 & 28,576 & 28,576 & 28,576 \\
\hline R-squared & 0.22 & 0.21 & 0.22 & 0.32 & 0.30 \\
\hline Adj. R-squared & 0.04 & 0.04 & 0.04 & 0.16 & 0.13 \\
\hline \multicolumn{6}{|c|}{ Dependent variables are as a fraction of Amount Outstanding multiplied by 100.} \\
\hline \multicolumn{6}{|c|}{ Robust standard errors in parentheses. } \\
\hline \multicolumn{6}{|c|}{$* * * p<0.01, * * p<0.05, * p<0.10$} \\
\hline
\end{tabular}


Table 4. Estimates of life insurer bond activity as a function of bond liquidity including liquidity-year interaction terms.

\begin{tabular}{|c|c|c|c|}
\hline & $\begin{array}{c}\text { (1) } \\
\text { Net Purchases }\end{array}$ & $\begin{array}{c}\text { (2) } \\
\text { Gross Purchases }\end{array}$ & $\begin{array}{c}(3) \\
\text { Sales }\end{array}$ \\
\hline \multirow[t]{2}{*}{ Turnover * $Y_{2005}$} & $-1.23 * * *$ & $0.66 * * *$ & $1.90 * * *$ \\
\hline & $(0.237)$ & $(0.198)$ & $(0.201)$ \\
\hline \multirow[t]{2}{*}{ Turnover $* Y_{2006}$} & $-0.85 * * *$ & 0.21 & $1.10 * * *$ \\
\hline & $(0.233)$ & $(0.170)$ & $(0.194)$ \\
\hline \multirow[t]{2}{*}{ Turnover $* Y_{2007}$} & -0.74 & -0.07 & $0.59 * * *$ \\
\hline & $(0.521)$ & $(0.398)$ & $(0.196)$ \\
\hline \multirow{2}{*}{ Turnover $* Y_{2008}$} & $-0.81 * * *$ & -0.08 & $0.66^{* * *}$ \\
\hline & $(0.223)$ & $(0.156)$ & $(0.215)$ \\
\hline \multirow{2}{*}{ Turnover $* Y_{2009}$} & 0.06 & -0.02 & -0.04 \\
\hline & $(0.273)$ & $(0.132)$ & (0.219) \\
\hline \multirow[t]{2}{*}{ Turnover $* Y_{2010}$} & $-0.29 * * *$ & $-0.44 * * *$ & -0.14 \\
\hline & $(0.103)$ & $(0.073)$ & (0.094) \\
\hline \multirow[t]{2}{*}{ Turnover $* Y_{2011}$} & $-0.33 * * *$ & $-0.31 * * *$ & 0.02 \\
\hline & $(0.084)$ & $(0.061)$ & $(0.082)$ \\
\hline \multirow[t]{2}{*}{ Turnover $* Y_{2012}$} & -0.03 & $-0.77 * * *$ & $-0.75 * * *$ \\
\hline & $(0.105)$ & $(0.073)$ & $(0.096)$ \\
\hline \multirow{2}{*}{ Turnover $* Y_{2013}$} & $1.17^{* * *}$ & $1.58 * * *$ & $0.46 * *$ \\
\hline & $(0.251)$ & $(0.147)$ & $(0.220)$ \\
\hline \multirow{2}{*}{ Turnover $* Y_{2014}$} & -0.34 & $1.37^{* * *}$ & $1.79 * * *$ \\
\hline & $(0.346)$ & $(0.166)$ & $(0.321)$ \\
\hline \multirow[t]{2}{*}{ Amihud $* 100 * Y_{2005}$} & $-209.45 * * *$ & $-87.90 * * *$ & $122.20 * * *$ \\
\hline & $(41.022)$ & $(26.627)$ & (35.087) \\
\hline \multirow[t]{2}{*}{ Amihud $* 100 * Y_{2006}$} & $-95.15^{* * *}$ & -22.29 & $75.35^{* * *}$ \\
\hline & $(29.886)$ & $(17.116)$ & $(26.050)$ \\
\hline \multirow[t]{2}{*}{ Amihud $* 100 * Y_{2007}$} & $-62.11 *$ & -9.21 & $48.27^{* *}$ \\
\hline & $(34.045)$ & $(24.809)$ & $(23.600)$ \\
\hline \multirow[t]{2}{*}{ Amihud $* 100 * Y_{2008}$} & -0.11 & $-17.68 * *$ & -16.73 \\
\hline & $(12.018)$ & $(7.732)$ & $(10.272)$ \\
\hline \multirow[t]{2}{*}{ Amihud $* 100 * Y_{2009}$} & -33.32 & -7.39 & 17.50 \\
\hline & $(26.347)$ & (7.319) & $(20.080)$ \\
\hline \multirow[t]{2}{*}{ Amihud $* 100 * Y_{2010}$} & $-34.01 * *$ & $-28.91 * * *$ & 7.06 \\
\hline & $(13.798)$ & $(7.002)$ & $(12.814)$ \\
\hline \multirow[t]{2}{*}{ Amihud $* 100 * Y_{2011}$} & 19.99 & $-18.49 * *$ & $-37.42 * * *$ \\
\hline & $(12.721)$ & (7.771) & $(11.151)$ \\
\hline \multirow[t]{2}{*}{ Amihud $* 100 * Y_{2012}$} & 5.04 & 9.63 & 8.06 \\
\hline & $(17.854)$ & (7.960) & $(16.040)$ \\
\hline \multirow[t]{2}{*}{ Amihud $* 100 * Y_{2013}$} & $124.73 * * *$ & $-28.05^{*}$ & $-142.76 * * *$ \\
\hline & $(27.385)$ & (15.333) & $(23.778)$ \\
\hline Amihud $* 100 * Y_{2014}$ & $133.88 * * *$ & $-42.94 *$ & $-161.19 * * *$ \\
\hline
\end{tabular}




\begin{tabular}{|c|c|c|c|}
\hline & $(37.760)$ & $(22.217)$ & $(33.504)$ \\
\hline \multirow[t]{2}{*}{$Y_{2006}$} & $-2.77 * * *$ & $-1.15^{* * *}$ & $1.55^{* * *}$ \\
\hline & $(0.414)$ & $(0.311)$ & $(0.343)$ \\
\hline \multirow[t]{2}{*}{$Y_{2007}$} & $-3.22 * * *$ & $-0.74^{*}$ & $2.68 * * *$ \\
\hline & $(0.591)$ & $(0.442)$ & (0.339) \\
\hline \multirow[t]{2}{*}{$Y_{2008}$} & $-4.41 * * *$ & $-2.01 * * *$ & $2.56^{* * *}$ \\
\hline & $(0.423)$ & $(0.311)$ & $(0.369)$ \\
\hline \multirow{2}{*}{$Y_{2009}$} & $-5.53 * * *$ & $-1.95^{* * *}$ & $3.55^{* * *}$ \\
\hline & $(0.640)$ & $(0.310)$ & $(0.510)$ \\
\hline \multirow[t]{2}{*}{$Y_{2010}$} & $-5.17 * * *$ & $-2.32 * * *$ & $2.86^{* * *}$ \\
\hline & $(0.419)$ & $(0.289)$ & $(0.353)$ \\
\hline \multirow[t]{2}{*}{$Y_{2011}$} & $-6.32 * * *$ & $-3.31 * * *$ & $3.04 * * *$ \\
\hline & $(0.400)$ & $(0.286)$ & $(0.335)$ \\
\hline \multirow[t]{2}{*}{$Y_{2012}$} & $-7.89 * * *$ & $-3.09 * * *$ & $4.84^{* * *}$ \\
\hline & $(0.411)$ & $(0.288)$ & $(0.345)$ \\
\hline \multirow[t]{2}{*}{$Y_{2013}$} & $-9.01 * * *$ & $-4.63 * * *$ & $4.38 * * *$ \\
\hline & $(0.444)$ & $(0.293)$ & $(0.377)$ \\
\hline \multirow[t]{2}{*}{$Y_{2014}$} & $-8.68 * * *$ & $-5.07 * * *$ & $3.58^{* * *}$ \\
\hline & $(0.465)$ & $(0.298)$ & $(0.404)$ \\
\hline \multirow[t]{2}{*}{ Constant } & $4.87 * * *$ & $5.06 * * *$ & 0.15 \\
\hline & $(0.369)$ & $(0.275)$ & $(0.301)$ \\
\hline Bond Fixed Effects & Yes & Yes & Yes \\
\hline Observations & 28,495 & 28,495 & 28,495 \\
\hline R-squared & 0.22 & 0.33 & 0.30 \\
\hline Adj. R-squared & 0.04 & 0.17 & 0.14 \\
\hline
\end{tabular}


Figure 1. Corporate bond holdings of securities brokers and dealers, 1990Q1-2015Q3

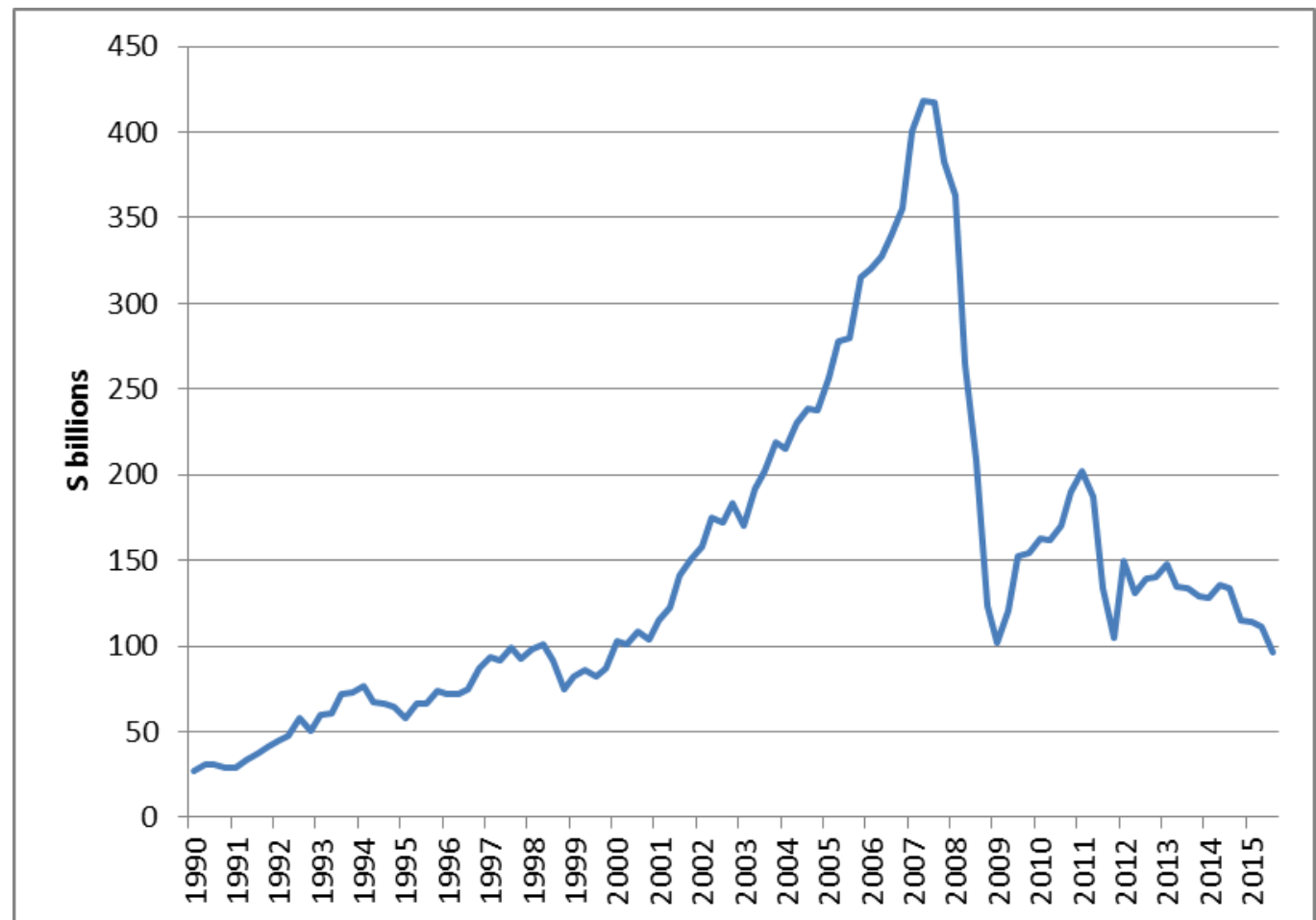

Note: The chart shows the quantity of corporate and foreign bonds (held in the United States) owned by securities brokers and dealers.

Source: Flow of Funds data from the Federal Reserve Board. 
Figure 2: Secondary market investment grade corporate bond trade volume and insurance purchases and sales as a percent of total, $2005-2014$

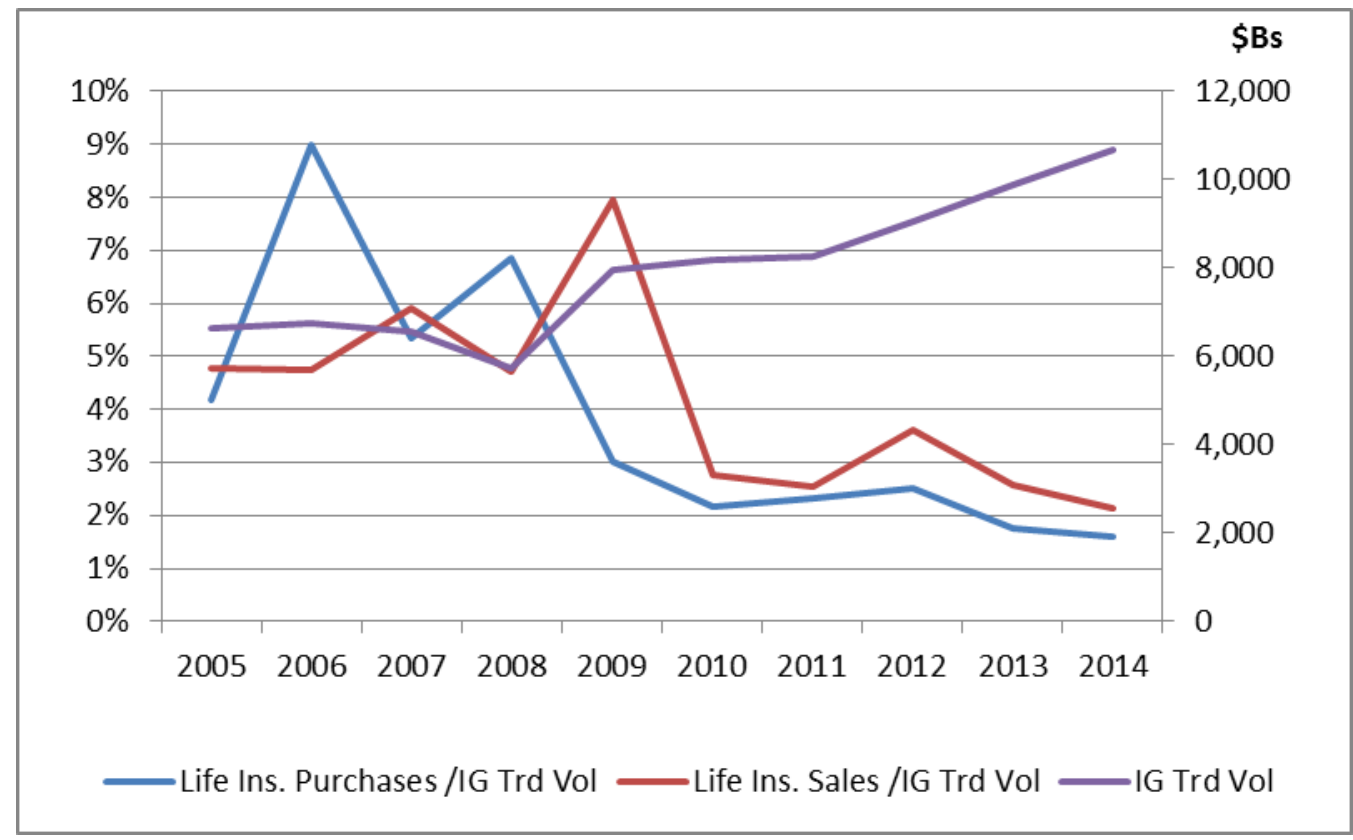

Source: Authors' calculations based on data from SNL Financial and TRACE. Only trades that occur at least 6 months post issuance are included. 
Figure 3. Investment grade corporate bond turnover rate compared to insurance company investment grade corporate bond trading in the secondary market, 2005-2014.

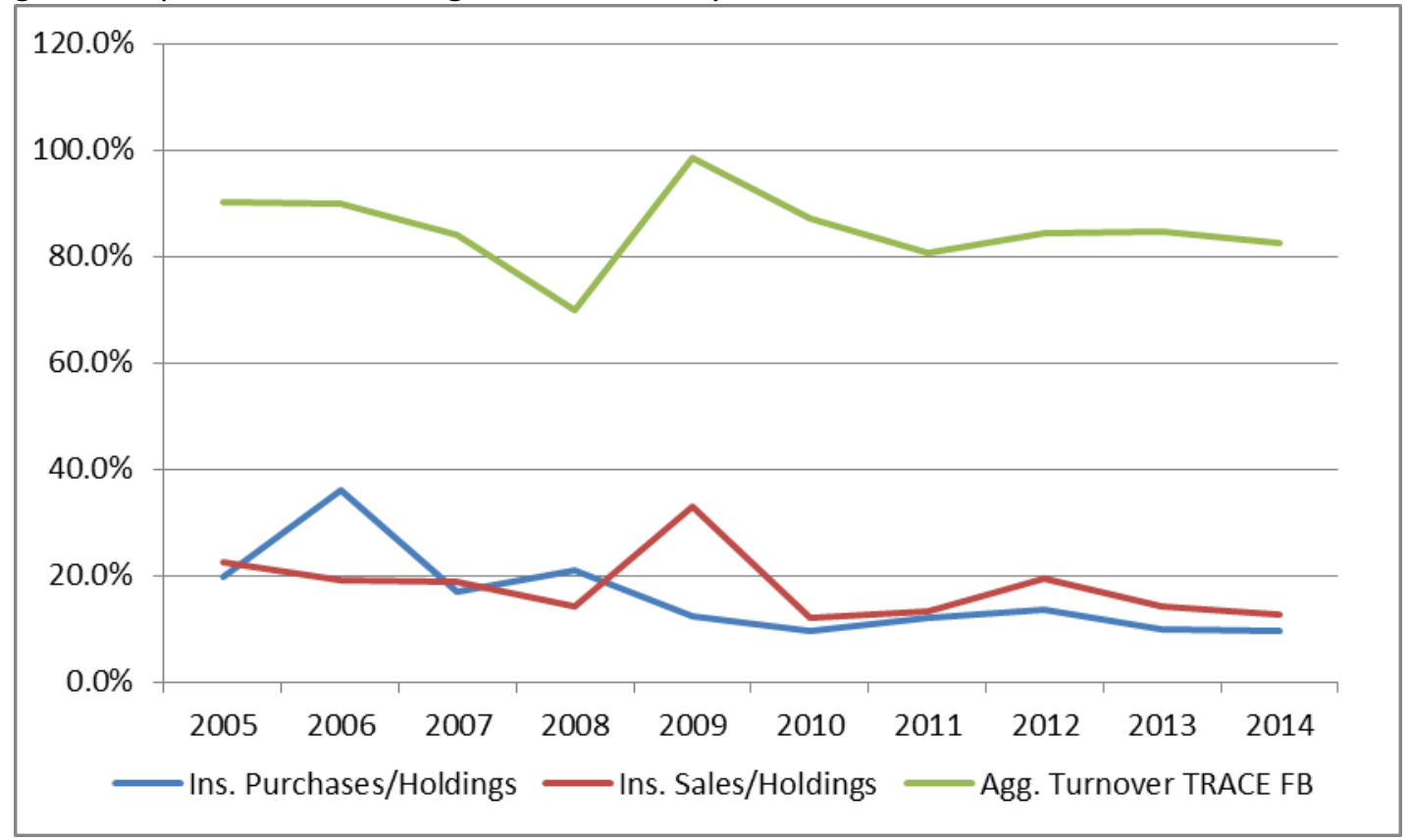

Aggregate turnover rate is total sales of investment grade corporate bonds in a year (as measured by TRACE) divided by the total amount outstanding for all investment grade corporate bonds. Insurance purchases/holdings are the total purchases of investment grade corporate bonds by life insurers in a year divided by the par value of the investment grade corporate bonds they owned at the start of the year. Insurance sales/holdings are defined analogously. Only sales and purchases that occur at least 6 months post issuance are included.

Source: Authors' calculations based on data from SNL Financial, TRACE, and Mergent. 
Figure 4. Regression coefficients

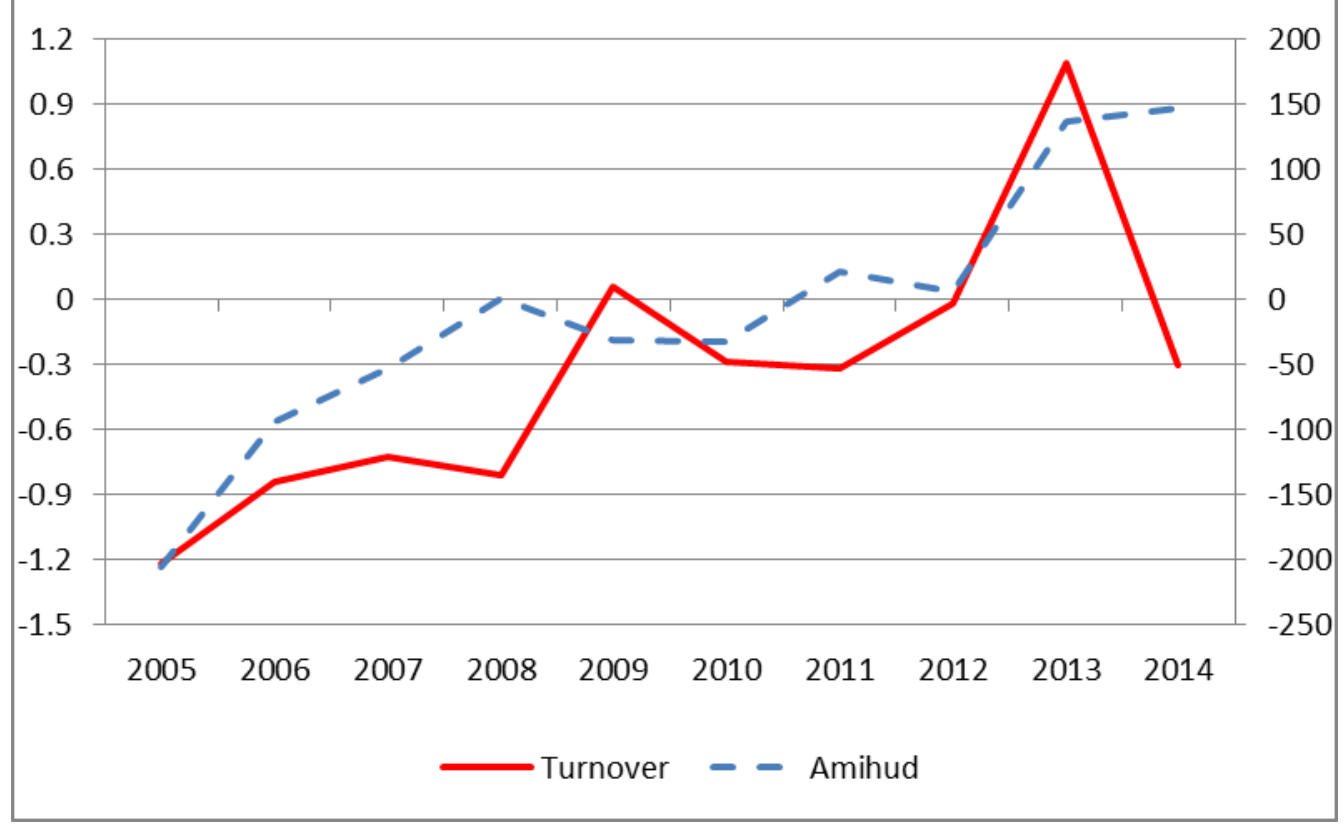

Coefficients from estimates of equation [2] with net purchases as the dependent variable. These coefficients are reported in column 1 of Table 4.

Source: Authors' calculations based on data from SNL Financial, TRACE, and Mergent. 


\section{Working Paper Series}

A series of research studies on regional economic issues relating to the Seventh Federal Reserve District, and on financial and economic topics.

The Urban Density Premium across Establishments

WP-13-01

R. Jason Faberman and Matthew Freedman

Why Do Borrowers Make Mortgage Refinancing Mistakes?

WP-13-02

Sumit Agarwal, Richard J. Rosen, and Vincent Yao

Bank Panics, Government Guarantees, and the Long-Run Size of the Financial Sector:

Evidence from Free-Banking America

WP-13-03

Benjamin Chabot and Charles C. Moul

Fiscal Consequences of Paying Interest on Reserves

WP-13-04

Marco Bassetto and Todd Messer

Properties of the Vacancy Statistic in the Discrete Circle Covering Problem

WP-13-05

Gadi Barlevy and H. N. Nagaraja

Credit Crunches and Credit Allocation in a Model of Entrepreneurship

WP-13-06

Marco Bassetto, Marco Cagetti, and Mariacristina De Nardi

Financial Incentives and Educational Investment:

The Impact of Performance-Based Scholarships on Student Time Use

WP-13-07

Lisa Barrow and Cecilia Elena Rouse

The Global Welfare Impact of China: Trade Integration and Technological Change

WP-13-08

Julian di Giovanni, Andrei A. Levchenko, and Jing Zhang

Structural Change in an Open Economy

WP-13-09

Timothy Uy, Kei-Mu Yi, and Jing Zhang

The Global Labor Market Impact of Emerging Giants: a Quantitative Assessment Andrei A. Levchenko and Jing Zhang

WP-13-10

Size-Dependent Regulations, Firm Size Distribution, and Reallocation

WP-13-11

François Gourio and Nicolas Roys

Modeling the Evolution of Expectations and Uncertainty in General Equilibrium

WP-13-12

Francesco Bianchi and Leonardo Melosi

Rushing into the American Dream? House Prices, the Timing of Homeownership, and the Adjustment of Consumer Credit

WP-13-13

Sumit Agarwal, Luojia Hu, and Xing Huang 


\section{Working Paper Series (continued)}

The Earned Income Tax Credit and Food Consumption Patterns

WP-13-14

Leslie McGranahan and Diane W. Schanzenbach

Agglomeration in the European automobile supplier industry

WP-13-15

Thomas Klier and Dan McMillen

Human Capital and Long-Run Labor Income Risk

WP-13-16

Luca Benzoni and Olena Chyruk

The Effects of the Saving and Banking Glut on the U.S. Economy

WP-13-17

Alejandro Justiniano, Giorgio E. Primiceri, and Andrea Tambalotti

A Portfolio-Balance Approach to the Nominal Term Structure

WP-13-18

Thomas B. King

Gross Migration, Housing and Urban Population Dynamics

WP-13-19

Morris A. Davis, Jonas D.M. Fisher, and Marcelo Veracierto

Very Simple Markov-Perfect Industry Dynamics

WP-13-20

Jaap H. Abbring, Jeffrey R. Campbell, Jan Tilly, and Nan Yang

Bubbles and Leverage: A Simple and Unified Approach

WP-13-21

Robert Barsky and Theodore Bogusz

The scarcity value of Treasury collateral:

Repo market effects of security-specific supply and demand factors

WP-13-22

Stefania D'Amico, Roger Fan, and Yuriy Kitsul

Gambling for Dollars: Strategic Hedge Fund Manager Investment

Dan Bernhardt and Ed Nosal

WP-13-23

Cash-in-the-Market Pricing in a Model with Money and

Over-the-Counter Financial Markets

WP-13-24

Fabrizio Mattesini and Ed Nosal

An Interview with Neil Wallace

WP-13-25

David Altig and Ed Nosal

Firm Dynamics and the Minimum Wage: A Putty-Clay Approach

WP-13-26

Daniel Aaronson, Eric French, and Isaac Sorkin

Policy Intervention in Debt Renegotiation:

Evidence from the Home Affordable Modification Program

WP-13-27

Sumit Agarwal, Gene Amromin, Itzhak Ben-David, Souphala Chomsisengphet,

Tomasz Piskorski, and Amit Seru 


\section{Working Paper Series (continued)}

The Effects of the Massachusetts Health Reform on Financial Distress

WP-14-01

Bhashkar Mazumder and Sarah Miller

Can Intangible Capital Explain Cyclical Movements in the Labor Wedge?

WP-14-02

François Gourio and Leena Rudanko

Early Public Banks

William Roberds and François R. Velde

WP-14-03

Mandatory Disclosure and Financial Contagion

WP-14-04

Fernando Alvarez and Gadi Barlevy

The Stock of External Sovereign Debt: Can We Take the Data at 'Face Value'?

WP-14-05

Daniel A. Dias, Christine Richmond, and Mark L. J. Wright

Interpreting the Pari Passu Clause in Sovereign Bond Contracts:

It's All Hebrew (and Aramaic) to Me

WP-14-06

Mark L. J. Wright

AIG in Hindsight

WP-14-07

Robert McDonald and Anna Paulson

On the Structural Interpretation of the Smets-Wouters "Risk Premium" Shock

WP-14-08

Jonas D.M. Fisher

Human Capital Risk, Contract Enforcement, and the Macroeconomy

WP-14-09

Tom Krebs, Moritz Kuhn, and Mark L. J. Wright

Adverse Selection, Risk Sharing and Business Cycles

WP-14-10

Marcelo Veracierto

Core and 'Crust': Consumer Prices and the Term Structure of Interest Rates

WP-14-11

Andrea Ajello, Luca Benzoni, and Olena Chyruk

The Evolution of Comparative Advantage: Measurement and Implications

WP-14-12

Andrei A. Levchenko and Jing Zhang

Saving Europe?: The Unpleasant Arithmetic of Fiscal Austerity in Integrated Economies

WP-14-13

Enrique G. Mendoza, Linda L. Tesar, and Jing Zhang

Liquidity Traps and Monetary Policy: Managing a Credit Crunch

WP-14-14

Francisco Buera and Juan Pablo Nicolini

Quantitative Easing in Joseph's Egypt with Keynesian Producers

WP-14-15

Jeffrey R. Campbell 


\section{Working Paper Series (continued)}

Constrained Discretion and Central Bank Transparency

WP-14-16

Francesco Bianchi and Leonardo Melosi

Escaping the Great Recession

WP-14-17

Francesco Bianchi and Leonardo Melosi

More on Middlemen: Equilibrium Entry and Efficiency in Intermediated Markets

WP-14-18

Ed Nosal, Yuet-Yee Wong, and Randall Wright

Preventing Bank Runs

WP-14-19

David Andolfatto, Ed Nosal, and Bruno Sultanum

WP-14-20

The Impact of Chicago's Small High School Initiative

Lisa Barrow, Diane Whitmore Schanzenbach, and Amy Claessens

Credit Supply and the Housing Boom

WP-14-21

Alejandro Justiniano, Giorgio E. Primiceri, and Andrea Tambalotti

The Effect of Vehicle Fuel Economy Standards on Technology Adoption

WP-14-22

Thomas Klier and Joshua Linn

What Drives Bank Funding Spreads?

WP-14-23

Thomas B. King and Kurt F. Lewis

Inflation Uncertainty and Disagreement in Bond Risk Premia

WP-14-24

Stefania D'Amico and Athanasios Orphanides

Access to Refinancing and Mortgage Interest Rates:

WP-14-25

HARPing on the Importance of Competition

Gene Amromin and Caitlin Kearns

Private Takings

Alessandro Marchesiani and Ed Nosal

WP-14-26

Momentum Trading, Return Chasing, and Predictable Crashes

WP-14-27

Benjamin Chabot, Eric Ghysels, and Ravi Jagannathan

Early Life Environment and Racial Inequality in Education and Earnings in the United States

WP-14-28

Kenneth Y. Chay, Jonathan Guryan, and Bhashkar Mazumder

Poor (Wo)man's Bootstrap

WP-15-01

Bo E. Honoré and Luojia Hu

Revisiting the Role of Home Production in Life-Cycle Labor Supply

WP-15-02

R. Jason Faberman 


\section{Working Paper Series (continued)}

Risk Management for Monetary Policy Near the Zero Lower Bound

WP-15-03

Charles Evans, Jonas Fisher, François Gourio, and Spencer Krane

Estimating the Intergenerational Elasticity and Rank Association in the US:

Overcoming the Current Limitations of Tax Data

WP-15-04

Bhashkar Mazumder

External and Public Debt Crises

WP-15-05

Cristina Arellano, Andrew Atkeson, and Mark Wright

The Value and Risk of Human Capital

WP-15-06

Luca Benzoni and Olena Chyruk

Simpler Bootstrap Estimation of the Asymptotic Variance of U-statistic Based Estimators

WP-15-07

Bo E. Honoré and Luojia Hu

Bad Investments and Missed Opportunities?

Postwar Capital Flows to Asia and Latin America

Lee E. Ohanian, Paulina Restrepo-Echavarria, and Mark L. J. Wright

WP-15-08

Backtesting Systemic Risk Measures During Historical Bank Runs

WP-15-09

Christian Brownlees, Ben Chabot, Eric Ghysels, and Christopher Kurz

What Does Anticipated Monetary Policy Do?

WP-15-10

Stefania D'Amico and Thomas B. King

Firm Entry and Macroeconomic Dynamics: A State-level Analysis

WP-16-01

François Gourio, Todd Messer, and Michael Siemer

Measuring Interest Rate Risk in the Life Insurance Sector: the U.S. and the U.K.

WP-16-02

Daniel Hartley, Anna Paulson, and Richard J. Rosen

Allocating Effort and Talent in Professional Labor Markets

WP-16-03

Gadi Barlevy and Derek Neal

The Life Insurance Industry and Systemic Risk: A Bond Market Perspective

WP-16-04

Anna Paulson and Richard Rosen 